COGNitiVe STUdies | Études COGNitives, 11

SOW Publishing House, Warsaw 2011

\author{
DANUTA ROSZKO ${ }^{1}$, ROMAN ROSZKO ${ }^{2}$ \\ ${ }^{1}$ Institute of Slavic Studies, Polish Academy of Sciences, Warsaw, Poland \\ (danuta.roszko@ispan.waw.pl) \\ ${ }^{2}$ Institute of Slavic Studies, Polish Academy of Sciences, Warsaw, Poland \\ (roman.roszko@ispan.waw.pl)
}

\title{
DIFFERENCES IN THE FORMALIZATION OF THE SEMANTIC CATEGORY OF DEFINITENESS / INDEFINITENESS
}

\begin{abstract}
Basing on theoretical contrastive studies guidelines, the article defines the semantic category of definiteness/indefiniteness where two basic opposition meanings are being ascribed to. It also distinguishes crucial sub-meanings for this category. The category established like this constitutes a characteristic interlanguage typical of theoretical contrastive studies, which is here used as tertium comparationis for demonstrating the formal differences between Polish, Lithuanian and dialectal exponents to express particular sub/meanings. The differences demonstrated in the article are to confirm a different degree of the formalization of the category in each of the natural codes compared here. The idea of taking the local dialect of Puńsk into consideration results from a clearly visible influence of Polish and Lithuanian on the traditional dialectal system. In consequence, the dialectal system of exponents to express the meanings within the semantic category of definiteness/indefiniteness keeps a high degree of the traditional exponents specialization on one hand, but on the other hand, a low degree of specialization is being ascribed to some forms borrowed from Lithuanian (as a consequence of the Polish language influence), which results from the bilingualism of the Lithuanians living in Poland.

Keywords: contrastive studies, interlanguage, semantic category of definiteness/indefiniteness, Lithuanian, Polish, Lithuanian local dialect of Puńsk in Poland.
\end{abstract}

\section{Introduction}

1.1. The article accepts all guidelines for theoretical contrastive studies (see that by Roszko, D. \& Roszko, R. to appear), on the basis of which the semantic category of definiteness/indefiniteness has been defined. The category established like this constitutes the content of the interlanguage, being tertium comparationis in the comparison of the three natural codes: Polish, Lithuanian and the local 
dialect of Punsk in Poland. It is assumed that the differences resulting from the comparison are to be observed on the formal grounds of the three codes/languages.

1.2. On the basis of traditional grammars, it is obvious that the morphological category of definiteness/indefiniteness has been developed in the Lithuanian language. The category is based on the opposition of the simple and compound forms of qualitative adjectives, participles (and so-called participle-like forms term used in the academic grammar of Lithuanian). About limitations of using the category, see the study by Roszko, D. \& Roszko R. to appear. The Polish language, like the majority of Slavic languages, has not developed the morphological category of definiteness/indefiniteness. The Lithuanian local dialect of Punsk in Poland is in vestigial form of the morphological category of definiteness/indefiniteness (see Macukonienè, Markevičienè 2006). As in the Lithuanian language, it is based on the opposition of the simple and compound forms of adjectives.

1.3. Taking the Lithuanian local dialect of Puńsk into consideration can be somewhat surprising. However, it is not accidental. In Poland, near the PolishLithuanian border, there live Lithuanians, who speak Lithuanian on an every-day basis. Till 1795, the regions of Puńsk were part of the Grand Duchy of Lithuania. After the third partition of Poland, they appeared within the borders of Prussia and Russia, respectively. After Poland regained its independence, they appeared within its borders.

From the linguistic analysis point of view, the lands occupied by the Lithuanian population have been for ages the meeting of many ethnic and linguistic borderlines. Just here runs the border between Balts and Slavs, also here runs the internal border between the eastern and the western groups of Slavs. Moreover, diversification of dialect can be witnessed in this rather little Lithuanian linguistic area in Poland. The Kapsu dialect (kapsu tarme in Lithuanian) and the territorially predominating Dzūku dialect ( $d z \bar{u} k u$ tarme in Lithuanian) keep the dialectal continuity with the country of Lithuania. Moreover, in the area of the Dzūku dialect, two local dialects are to be distinguished: one of Punsk and the other of Seinai.

Still, for a long period of time after the second world war, the Puńsk Lithuanians used exclusively a local dialect. Knowledge of the literary form of the Lithuanian language was rather rare. Similarly, knowledge of the literary form of the Polish language was not an obvious fact amongst the Puńsk Lithuanians. The changes that took place during the last decades resulted in the present Puńsk Lithuanians (particularly middle-aged and young generations) having a good command of the literary forms of both Polish and Lithuanian. This fact particularly concerns the population of secondary and higher education. The old generation to be found there still uses the local dialect. Whereas, the Polish spoken by them strongly reflects the features of the Polish local dialects. It can be also distinguished by certain East-Slavic linguistic influences.

\section{Semantic category of definiteness/indefiniteness}

In the second volume of Bulgarian-Polish Contrastive Grammar (Koseska, Gargov 1990, see also Koseska herein) there has been defined the interlanguage of semantic category of definiteness/indefiniteness. The category is based on the quantification theory. The unique quantification meanings put into the opposition to 
universal and existential meanings created the categorical opposition of definiteness to indefiniteness. In Koseska, Gargov 1990, the meanings of the uniqueness of the element and the uniqueness of the set form the definiteness. Whereas, the indefiniteness (or non-uniqueness) is formed by the meanings of existentiality and universality. The category of definiteness/indefiniteness has been recognized as the sentence category, scope-embracing both nominal and verbal phrases. For more information see Koseska, Gargov 1990, Koseska herein). For the purposes of the Polish-Lithuanian confrontation, the structure of the semantic category of definiteness/indefiniteness has been developed (see Roszko, R. 2004). Basing on the feature of gradation, new sub-meanings have been distinguished [a] existentiality: uniqueness presupposing existentiality and proper existentiality; [b] universality: habitual universality and proper universality. Moreover, the notions of the unambiguous exponents and the ambiguous exponents of the quantification meaning have been put into life. This last element of the category was singled out for the sake of the natural language computer processing (machine translations). The detailed description of the category and its subcategory is to be found in Roszko, R. 2004, whereas a brief description of the meanings along with examples is to be found in Roszko, D. \& Roszko, R. to appear.

\section{Definiteness}

\section{1. The meaning of uniqueness of the element and the set}

The exponents of uniqueness of the element and the set for the three languages compared are very much similar - both in the nominal and the verbal phrase. Nevertheless, there are certain differences that exist. The most important of them is connected with the pronominal declension of qualitative adjectives, participles and participle-like forms. This feature is above all distinctive for the Lithuanian language. It also appears in the Lithuanian local dialect of Punsk, but like that it is not so common as in the Lithuanian language. The sources of the experimental corpus of the local dialect of Puńsk prove that using the compound declension of adjectives for expressing the uniqueness meanings is incidental. Moreover, the analysis of specific uses shows that today a fixed set of fossilized forms is more common than the functioning category. Among the most common forms to note are: juodoj 'the black one', margoj 'the spotted one', jaunoj 'the young one', žaloj 'the claret one', amžinaj acilsi 'eternal rest', jaunasis 'bridegroom', jaunoji 'bride' and others. The feminine gender forms predominate. Using the compound declension of adjectives in the uniqueness function refers to the oldest corpus records. The young and middle-aged generations of the Lithuanians of Puńsk, in principle, do not use these linguistic forms. To similar conclusions come Macukonienė and Markevičienė (2006). Moreover, the authors notice that the young generation that is getting to know the literary version of the compound declension at school does not use it on an every-day basis, even at school. You may have a feeling that the correct use of the adjectival forms of the compound declension in the uniqueness function causes them certain problems. It is worthwhile here, however, making a note of the fact that the dialectal declension of the compound adjectives differs from the declension well-known in the Lithuanian language, compare, for example, the masc.: jaunasai 
(dial.) - jaunasis (Lith.) etc. The difference in forming the compound forms can also contribute to replacing the uses of these forms with other lexical means, e.g. with pronouns. For the reasons given here, Table 1 demonstrates the adjectival and participial forms of the compound declension as potential for the local dialect of Puńsk.

A further element distinguishing the Polish exponents from those of Lithuanian (incl. the local dialect) is the unambiguity of the uses of the Lithuanian/dialect pronouns of the tas type. Although, the Lithuanian./dialectal tas is equivalent to the Polish ten / tamten, in many cases it appears difficult to establish the formal Polish equivalent. Then the meaning of definiteness in Polish is to be seen in context or a particular situation. It is worth mentioning that the Polish ten / tamten are ambiguous. The Lithuanian and dialectal tas is an unambiguous exponent of the state uniqueness. Equally unambiguously interpreted are Lithuanian and dialectal neuter gender pronouns of the tai type. Because of the fact that in the Lithuanian language and the local dialect there are no nouns of neuter gender, and thus no compound phrases constructed on the nouns, the pronouns of neuter gender of the tai type are a more specialized exponents of uniqueness than their most frequent Polish equivalent to.

In the verbal phrase it is possible to distinguish the Lithuanian and dialectal present forms of imperfective stems ${ }^{1}$, which are unambiguous exponents of the state $^{2}$ uniqueness. In Polish, the quantification meaning of using the present forms is to be found in context or in a particular situation. The Polish present form is a typical representative of the quantification understatement.

Table 1. Exponents of uniqueness of the element and the set in Polish, Lithuanian and the Lithuanian local dialect of Puńsk - contrastive comparison.

\begin{tabular}{|c|c|c|}
\hline Polish & Lithuanian & Local dialect of Puńsk \\
\hline - & $\begin{array}{l}\text { adjectival, participial, and } \\
\text { participle-like of pronomi- } \\
\text { nal declension forms }\end{array}$ & $\begin{array}{l}\text { [adjectival, and participial } \\
\text { of pronominal declension } \\
\text { forms] }\end{array}$ \\
\hline $\begin{array}{l}\text { ten }_{1} / \text { tamten }_{1}(\mathrm{~m} .), t a_{1} \\
/ \operatorname{tamta}_{1}(\mathrm{~m} .)\end{array}$ & $\operatorname{tas}(\mathrm{m}),. \operatorname{ta}(\mathrm{f})$. & $\begin{array}{l}\text { tas }(\mathrm{m} .) \text {, tasai (m.) (com- } \\
\text { pound form), toj (f.) } \\
\text { (compound form) }\end{array}$ \\
\hline [indicative pronoun to ${ }_{1}$ ] & $\begin{array}{l}\text { indicative pronouns of } \\
\text { neuter gender: tai, tatai, } \\
\text { šitai, šitatai. }\end{array}$ & $\begin{array}{l}\text { pronoun of neuter gender } \\
\text { tai }\end{array}$ \\
\hline - & $\begin{array}{l}\text { present forms of imperfec- } \\
\text { tive stems }\end{array}$ & $\begin{array}{l}\text { present forms of imperfec- } \\
\text { tive stems }\end{array}$ \\
\hline
\end{tabular}

\footnotetext{
${ }^{1}$ In Lithuanian, the aspect is not ascribed to the verb as such , but to its particular stems, thus the aspect of the present tense stem, the past tense stem etc. is being referred to.

${ }^{2}$ States and events are being interpreted according to the Petri net theory.
} 
Examples from Lithuanian and Polish ${ }^{3}$ :

[1] Dešine ranka suemiau kairiosios riešą ir taip stipriai suspaudžiau, kad net kaulai trekštelëjo.

Prawą ręką ująłem kiść lewej i ścisnąłem ją z całej siły, aż kości chrupnęły.

[2] Jau galëjau sau pasakyti, kad visos abejonès buvo išsklaidytos ir pro tariamajji Harès veidą žvelgè kitas, tikrasis, ir dabar jau pamišimo alternatyva rodèsi išganymas.

Wszelkie pozory — to mogłem sobie powiedzieć — zostały zdarte i poprzez pozór twarzy Harey zaczęła przeglądać inna, prawdziwa, wobec której alternatywa obłędu rzeczywiście stawała się wyzwoleniem.

[3] - Kas tu toks? - išgirsta klausiant ispaniškai.

Jis pajunta didžiuli palengvèjimą. Ką tik mąstè apie ženklus, ir štai vienas...

— Kaip čia yra, kad tu kalbi ispaniškai? — paklausia vaikinas.

Priejusysis vilki vakarietiškais drabužiais, tačiau odos spalva liudija, kad jis vietinis. Vyrukas panašaus ūgio ir amžiaus kaip ir jis pats.

— Kim jesteś? — zapytał go ktoś po hiszpańsku.

Chłopiec odczuł ogromną ulgę. Akurat myślał o Znakach i oto ktoś się pojawił.

— Jak to możliwe, że mówisz tak dobrze po hiszpańsku? - spytał.

Nowo przybyty był młodym chłopakiem ubranym na sposób europejski, ale kolor jego skóry zdradzał, że pochodził stąd. Był mniej więcej jego rówieśnikiem.

[4] Trinktelëjau sunkų tomą i lentyną ir pasièmiau kitą. Jis buvo dviejų dalių. Pirmoji skirta santraukai protokolu visu $t \boldsymbol{t} u$ nesuskaičiuojamų eksperimentu, kurių tikslas buvo užmegzti kontaktą su okeanu.

Wstawiłem z trzaskiem wielki tom na półkę i wydobyłem następny. Dzielił się na dwie części. Pierwsza była poświęcona streszczeniu protokołów eksperymentalnych wszystkich owych niezliczonych przedsięwzięć, których celem było nawiązanie kontaktu z oceanem.

[5] Tarp nikeliniu ir plastikinių aparatų, aukštu spintų su elektronine aparatūra, stiklų, precizinių įrenginių tas išgveręs šlepsejjimas atrodè it paika kokio nepilnapročio išdaiga.

Pośród niklowych i plastykowych aparatów, wysokich szaf z elektronową aparaturą, szkieł, precyzyjnych aparatów ów człapiący, rozlazły chód brzmiał jak błazeńska sztuczka kogoś niespełna rozumu.

\footnotetext{
${ }^{3}$ The Polish and Lithuanian examples mentioned here come from the sources of the parallel Polish-Lithuanian corpus. The Lithuanian local dialect of Puńsk examples mentioned here come from the experimental dialect corpus.
} 
[6] Paskui aš pajutau, kad tas už durų rankeną atleido, ir išgirdau lengvą šnaresi - nuejjo. Pastovejjau dar klausydamasis, tačiau buvo tylu.

Potem odskoczyła mi nagle w dłoni - puszczona wolno, a słaby szelest świadczył, że tamten odchodzi. Stałem jeszcze nasłuchując, ale panowała cisza.

[7] Ir tas nepadejjo.

To było daremne.

[8] - Kaip $\mathbf{t a i}$ atsitiko?

— W jaki sposób?

[9] Sukiojausi, vildamasis, kad pagaliau man pavyks pakliūti į viena tų rūko neaptrauktu vietu, ir tikrai po kokio pusvalandžio man tas pavyko.

Krążyłem wciąż w nadziei, że w końcu uda mi się wypaść na jedno z tych wolnych od mgły miejsc, i rzeczywiście udało mi się, jakieś pół godziny potem.

[10] Simetriada yra milijonas, ne, milijardas, nepaprastai išdidintas, pati neįsivaizduojamybè; kas iš to, jei gilumoje kažkokios jos navos, kuri yra dešimteriopai padidinta Kronekerio erdvé, stovime it skruzdès, isikibusios i alsuojančių skliautų raukšles, jei matome skrydi gigantiškų plokštumų, pilkai žaižaruojančiu mūsų žibintu šviesoje, matome, kaip jos prasiskverbia į viena kitą ir sklandžiai, su neklaidingu tobulumu išsiformuoja — juk tai trunka tik momentą, nes čia viskas plaukia - tos architektonikos turinys yra judesys, sukauptas ir tikslingas.

Symetriada jest milionem, nie, miliardem podniesionym do potęgi, niewyobrażalnością samą; cóż stąd, że w głębi jakiejś jej nawy, będącej udziesięciokrotnioną przestrzenią Kroneckera, stoimy jak mrówki uczepione fałdy oddychającego sklepienia, że widzimy wzlot gigantycznych płaszczyzn, opalizujących szaro w świetle naszych flar, ich wzajemne przenikanie, miękkość i nieomylną doskonałość rozwiązania, które jest przecież tylko momentem bo tu wszystko płynie — treścią tej architektoniki jest ruch, skupiony i celowy.

In examples 1 to 4 , the Lithuanian sentences bear the forms of compound declension: kairiosios, tikrasis, priejusysis (participle) and pirmoji, which unambigually express the meaning of definiteness. In Polish, definiteness is being observed on the basis of cooperation of the forms lewej, prawdziwa, (nowo) przybyły and pierwsza with context.

In examples 4 to 7 , it is possible to observe the following correspondence: the Lithuanian lexeme tas - the unambiguous exponents of definiteness corresponds with different Polish lexemes: ów (in 4 and 5), tamten (in 6), ten (in 7), which are not the unambiguous exponents of definiteness. Even some contexts can be found in which these Polish forms are the exponentss of indefiniteness (here: proper existentiality), compare: Ten $i$ ów coś zrobit $i$ się rozeszli. Moreover, each of the Polish lexemes listed here contains the additional parameter referring to the distance in time or space. 
In examples 8 to 10, no formal element in the Polish sentences corresponds with the highlighted Lithuanian unambiguous exponents of definiteness.

Dialectal examples:

[11] Tasai viedras nor ir buvo sanesnis, ale drūtesnis, ilgiau laikè.

[12] Darèm kiek gałẻjom, ale ir tas nieko nepadejjo, žami turëjo parduoc.

Compare also the below-mentioned example 22, and the use of the dialectal tas in it.

\section{Indefiniteness}

\section{1. Existentiality}

\section{1. 1. The meaning of uniqueness presupposing existentiality}

In principle, we can speak about a high level of correspondence between the compared languages if not for the fact that the Polish pewien is not the unambiguous exponent of uniqueness presupposing existentiality. In some contexts, the Polish pewien - replaceable with pronouns containing the particle -ś (e.g. jakiś) - can be the exponent of proper existentiality. The Lithuanian form tam tikras (e.g. tam tikras žmogus 'certain man') is an unambiguous, highly-specialized exponent of uniqueness presupposing existentiality. The dialectal highly specialized exponent of uniqueness presupposing existentiality is vienas. The form vienas is well-known also for the literary form of Lithuanian; sometimes in dictionaries, it goes along with the label: colloquial expression. However, the local dialect of Puńsk does not include the literary form tam tikras. Young generations of the Polish Lithuanians get to know this form at school.

Table 2. Exponents of uniqueness presupposing existentiality in Polish, Lithuanian and the Lithuanian local dialect of Puńsk - contrastive comparison.

\begin{tabular}{|l|l|l|}
\hline Polish & Lithuanian & Local dialect of Puńsk \\
\hline pewien $x /$ jeden $x$ & tam tikras $x$ & - \\
\hline & vienas $x$ & vienas $x$ \\
\hline & & \\
\hline
\end{tabular}

Examples from Lithuanian and Polish:

[13] Tam tikra laika buvo populiari (uoliai laikraščiu skleidžiama) pažiūra, kad mąstantis okeanas, kuris supa visą Soliarį, yra gigantiškos smegenys, kurios, besivystydamos milijonus metų, pranoko mūsų civilizaciją. Tai esąs kažkoks „kosminis jogas“, išminčius, ikkūnyta visažinybè, kuri jau seniai suvokẻ bet kokios veiklos bevaisiškumą ir todèl kategoriškai atsisako su mumis bendrauti. 
Przez pewien czas popularny był (rozpowszechniany gorliwie przez prasę codzienną) pogląd, że myślący ocean, który opływa całą Solaris, jest gigantycznym mózgiem, przewyższającym naszą cywilizację o miliony lat rozwoju, że to jakiś „kosmiczny yoga", mędrzec, upostaciowana wszechwiedza, która dawno już pojęła płonność wszelkiego działania i dlatego zachowuje wobec nas kategoryczne milczenie.

[14] - Nežinau. Tam tikra prasme tas priklauso nuo tavęs.

- Nie wiem. W pewnym sensie to zależy od ciebie.

[15] Ir dar norěčiau tau papasakoti viena trumpa istoriją. Vienas turtuolis pasiuntė savo sūnų pas išmintingiausią pasaulyje žmogų sužinoti Laimės Paslapties.

Na koniec chciałbym ci opowiedzieć pewna historię. Raz pewien kupiec posłał swego syna po Tajemnicę Szczęścia do najmądrzejszego z ludzi.

[16] Tapsiu pikčiurna ir nebepasitikėsiu žmonėmis, nes vienas mane apvylè.

Co mam począć? Stanę się zgorzkniały i stracę zaufanie do ludzi, bo zawiódł mnie jeden człowiek.

In examples 13 to 14, the following correspondence is to observe: the Lith. tam tikras (an unambiguous means) corresponds with the Pol. pewien (an ambiguous means); in example 15, the Lith. vienas with the Pol. pewien; whereas in example 16, the Lith. vienas corresponds with the Pol. jeden człowiek. It is worth mentioning that in the Lithuanian sentence 16, a reduced phrase appears. Such a phenomenon is characteristic of the Lithuanian language, when one of the possible article-like forms appears in a phrase (e.g. tas, vienas, -jis). A similar phenomenon is being observed in the local dialect, compare the below-mentioned example 17 . And in example 41, compare an analogous case to those presented in 13 to 14 .

Dialectal example:

[17] Man vienas pasakè, kad jiej visi išèjo namo, cik jiej da liko ilgiau, norëjo da pašokc.

\subsubsection{The meaning of proper existentiality}

The typical exponents of proper existentiality in the Polish nominal phrase include pronouns, adverbial pronouns and adverbs with the particle -ś (ktoś, coś, jakiś, gdzieś, kiedyś etc.) and the adjective pewien. They are not unambiguous exponents. Pewien is also used to express the meanings of uniqueness presupposing existentiality, whereas the series of lexemes with the particle $-s$, also to express the meanings of habitual universality; compare the below-mentioned 4.2.1. Lithuanian compounds with the particle $k a \check{z}$ - are unambiguous, highly-specialized exponents of proper existentiality. A similar state can be observed in the local dialect of Puńsk, in which the phrases kokias ti / ti kokias play the same role. However, recently, the middle-aged and young generations of the Lithuanians of Puńsk have started 
using an exponent containing the particle $k a \check{z}$-, borrowed from the literary form of the language. Unfortunately, this form causes the Lithuanians of Puńsk a problem. It is rather used to express the meanings of both proper existentiality and habitual universality, like the Polish exponents with the particle $-s$. The reason for this state of things is supposed to result from lack of the formal analogy between the dialectal and literary exponents. The existence of structural analogies is believed to allow a dialectal exponent to be automatically exchanged with a literary one. However, it is impossible, on account of another formal structure of the two aspects: dialectal and literary. However, the bilingualism of the middle-aged and young generation can be the reason for moving the meaning of Polish forms with the particle -s onto the borrowed Lithuanian phrase with the particle $k a \check{z}$. In the literary Lithuanian language, non-borrowed forms kaži, kažin are to be found, which, however, have not been included in the lexis of the local dialect of Puńsk.

In the verbal phrase, the Lithuanian and dialectal perfect forms are unambiguous exponents of existentiality of the state or the event. The Polish past forms are quantificatively ambiguous.

Table 3. Exponents of proper existentiality in Polish, Lithuanian and the Lithuanian local dialect of Puńsk - contrastive comparison.

\begin{tabular}{|c|c|c|}
\hline Polish & Lithuanian & Local dialect of Puńsk \\
\hline $\begin{array}{l}\text { pewien } x \text { / series of lex- } \\
\text { emes with the particle }-s ́ \\
\text { (e.g. ktoś, coś, kiedyś, } \\
\text { gdzieś, jakoś, któryś etc.) }\end{array}$ & $\begin{array}{l}\text { series of lexemes with the } \\
\text { particle kaž-, kaži, kažin, } \\
\text { e.g. (kazkoks, kaži koks, } \\
\text { kažin koks etc.) }\end{array}$ & $\begin{array}{l}\text { series of lexemes with the } \\
\text { particle ti being in pre- } \\
\text { position or post-position, } \\
\text { e.g. kokias ti / ti kokias } \\
\text { etc. }\end{array}$ \\
\hline & & 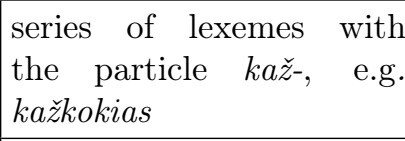 \\
\hline & & 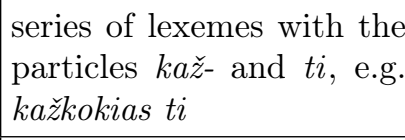 \\
\hline - & perfectum & perfectum \\
\hline
\end{tabular}

Examples from Lithuanian and Polish:

$$
\begin{aligned}
& \text { [18] — Jonuk! — garsiai sušnibždëjo jis. } \\
& \text { - Ką? } \\
& \text { - Rodos, bitès } k a r z k a \text { ittaria. } \\
& \text { - O ką? } \\
& \text { - Nežinau. Bet jaučiu, kad jos yra i t a r i o s. } \\
& \text { - Krzysiu! } \\
& -\mathrm{Co} \text { ? }
\end{aligned}
$$


—Zdaje mi się, że pszczoły $c$ o $\quad s$ zwąchały.

- A co takiego?

— Nie wiem, ale mam wrażenie, że one się czegoś domyślają.

[19] Už žemėlapio kažkas kabojo.

Za mapa $\cos$ wisiało.

[20] — Kadaise radau jas laukuose. Ketinau atiduoti tau įšventinimo dieną.

— Znalazłem je kiedyś w polu i zamierzałem ofiarować Kościołowi w dniu twoich święceń.

[21] Piemeniui parduotuvę buvo nurodęs draugas, ir jis ten atvarè savają bandą.

Jakiś przygodny znajomy wskazał pasterzowi ten sklep, więc pognał tam swoje stado.

In the above examples, the Lithuanian-Polish equivalences have been demonstrated to express the meanings of proper existentiality. In addition to the expected pairs: the Lithuanian form with the particle $k a z ̌$ - corresponding with the Polish form with the particle $-s$, the using of the Lithuanian perfectum form conditioning the existential quantification can be observed, compare in 18 yra itarios, and in 21 buvo nurodęs.

Dialectal examples:

[22] An stało buvo ti kas padèta, kur dartes yra tas?

[23] Vakar atveže ti kokias knygas, nežinau ar tokias kokiu nori.

[24] Akmuoj, akmuoj, pats akmuoj pastacic, tai dar jis ti tokias ar kitokias, ale kadu norejo uždec kryžo, turi buc biski kažkas panašaus, ba kap tai, jaigu jis bus kokias va šleivas, tai ca ješkojom

Comp. also more low example 38., and in it expressions ti kokias.

\subsection{Universality}

\subsubsection{The meaning of habitual universality}

To express the meanings of habitual universality in the Lithuanian language, the forms with the particle nors are being used, among others. The Polish compound phrases including a pronoun, adverbial pronoun or adverb with the particle -s (e.g. jakiś, jakieś etc.) are set with their Lithuanian equivalents. The Lithuanian forms with the particle nors are an unambiguous, highly-specialized exponent of the meanings of habitual universality. In Polish, the mentioned forms with the particle $-s$ are referred to as ambiguous. The Polish forms with the particle $-s$ are also exponents of the meanings of proper existentiality, compare the above 4.1.2. On account of the fact that the Polish language consequently does not distinguish any general habitual or proper general contents on the formal grounds, sometimes a 
pronoun, adverbial pronoun or adverb with the particle -kolwiek (e.g. jakokolwiek) appears in the function of habitual universality.

In the local dialect of Puńsk, pronouns and adverbs enriched with the particle $t i$, e.g. kokias ti are exponents of the meanings of habitual universality. As it is easy to notice, an identical form of exponent takes place in the local dialect as the exponent of proper existentiality. However, it should be emphasized that in case of proper existentiality, the particle $t i$ is in pre-position, whereas, in case of habitual universality, it is in post-position. Moreover, it is often omitted, and then the meanings of habitual universality are being read/deducted from the pure form of pronoun or adverb, like in the literary Lithuanian language.

The Lithuanian language developed another exponent functioning in the nominal phrase. It is an adjective, participle or participle-like form of compound declension, e.g. mylimasis (usually every lover). The use of such forms of compound declension is not familiar to the local dialect.

In Lithuanian and in the dialectal verbal phrase, a typical exponent of habitual universality is the past interactive form. Similarly, the present forms of perfective stems as well as of point and momentary verbs (e.g. dingti 'vanish', rasti 'find') are an unambiguous exponent of the meanings of habitual universality.

Table 4. Exponents of habitual universality in Polish, Lithuanian and the Lithuanian local dialect of Puńsk - contrastive comparison.

\begin{tabular}{|c|c|c|}
\hline Polish & Lithuanian & Local dialect of Puńsk \\
\hline \multirow[t]{3}{*}{$\begin{array}{l}\text { series of lexemes with the } \\
\text { particle }-s \text { / series of lex- } \\
\text { emes with the particle - } \\
\text { kolwiek, e.g. jakiś } \\
\text { jakikolwiek }\end{array}$} & $\begin{array}{l}\text { series of lexemes with the } \\
\text { particle nors, e.g. koks } \\
\text { nors }\end{array}$ & $\begin{array}{l}\text { series of lexemes with the } \\
\text { particle ti, e.g. kokias ti }\end{array}$ \\
\hline & $\begin{array}{l}\text { pure form of pronoun, } \\
\text { adverb or adverbial pro- } \\
\text { noun, e.g. kas }\end{array}$ & $\begin{array}{l}\text { pure form of pronoun, ad- } \\
\text { verb or adverbial pronoun, } \\
\text { e.g. kas }\end{array}$ \\
\hline & & $\begin{array}{l}\text { series of lexemes with } \\
\text { the participle kaž-, e.g. } \\
\text { kažkokias }\end{array}$ \\
\hline - & $\begin{array}{l}\text { adjectival, participial and } \\
\text { participle-like forms of } \\
\text { pronominal declension } \\
\text { (-jis, -ji), e.g. gerasis (m. } \\
\text { sg.), geroji (f. sg.), gerieji } \\
\text { (m. pl.), gerosios (f. pl.) }\end{array}$ & \\
\hline- & past iterative & past iterative \\
\hline - & $\begin{array}{l}\text { present forms of perfective } \\
\text { stems as well as of point } \\
\text { and momentary verbs }\end{array}$ & $\begin{array}{l}\text { present forms of perfective } \\
\text { stems as well as of point } \\
\text { and momentary verbs }\end{array}$ \\
\hline
\end{tabular}


[25] — Būsi ją kur nors palikęs, tarè Pūkuotukas.

- Kas nors bus pasièmęs,- pasakè Nulèpausis. - Va kokie,- - pridūrè ilgokai patylëjęs.

- Musiałeś go gdzieś zostawić — rzekł Kubuś Puchatek.

— Ktoś musiał mi go zabrać — powiedział Kłapouchy. — I jak tu mieć dla nich serce? — dodał po dłuższej chwili milczenia.

[26] - Kai tikrai ko nors trokšti, visas pasaulis slapta padeda tau igyvendinti tą troškimą, - senojo karaliaus žodžiais atsako Alchemikas.

- Kiedy się czegoś pragnie, wtedy cały wszechświat sprzysięga się, byśmy mogli spełnić nasze marzenie — powiedział Alchemik, powtarzając słowa Starego Króla.

[27] — Kas gi nèra kada nors sapnavęs tokio sapno?

- Któż nie miał kiedyś takiego snu?

[28] Nèra jo Stotyje? Išskrido kur?

Nie ma go na Stacji? Poleciał gdzieś?

[29] Ar buvai ji $\boldsymbol{k a d a}$ anksčiau matęs?

Czy widziałeś je kiedyś w życiu gdziekolwiek?

[30] Pirmasis mokytojas visada išlieka širdyje.

[31] „Pirmieji potyriai visada išlieka giliai širdyje. Džiaugiuosi, kad teko dalyvauti tokiame konkurse, kuriame iš tiesų vertinama muzika. Nors jau esu dalyvavęs jame tris kartus, iki šiol trokštu ten nuvykti“, — tikina jaunuolis.

[32] Tikrasis vairuotojas sèda prie vairo ir, jei nèra centrinio užrakto, ranka iš vidaus atidaro kitas dureles.

[33] Tylioji kiaulè gilią šakni knisą.

[34] Alchemikas žino legendą apie Narcizą - gražuolį, kuris kiekvieną dieną ateidavo prie ežero gèrètis savo atspindžiu vandenyje.

Alchemik dobrze znał mit o Narcyzie, owym urodziwym młodzieńcu, który chodził codziennie podziwiać własne odbicie w tafli jeziora.

[35] - Jau labai seniai aš ateidavau prie šio šulinio laukti tavęs.

- Od dawna czekam na ciebie przy tej studni.

[36] Pas Snautą ar Sartorijų man nebuvo ko eiti, neịsivaizdavau, kad kas galètu sujungti i visumą tai, ką ligšiol pergyvenau, ką mačiau, ką liečiau savo rankomis.

Nie miałem po co iść do Snauta czy Sartoriusa, nie wyobrażałem sobie, żeby ktokolwiek mógł złożyć w całość to, co dotychczas przeżyłem, co widziałem, czego dotykałem własnymi rękami. 
In examples 25 to 27 the most frequent equivalence of Lithuanian compound phrases containing the particle nors and Polish phrases containing the particle -ś is apparent. The Lithuanian nors marks the phrase as habitual universality. The Polish -s, however, is typical of the meanings of both proper existentiality and habitual universality.

In examples 28 to 29 , another way of expressing the habitual universality is exposed - the pure/independent using of a pronoun or adverb. Also in the examples, the Lithuanian forms correspond with the Polish phrases containing the particle $-s$.

In examples 30 to 33 , the forms of compound declension are exponents of habitual universality. In the experimental Polish-Lithuanian corpus there is lack of Polish equivalents. The examples 30 to 32 come from the texts which until now have not been translated into Polish. Example 33 is a Lithuanian proverb.

In examples 34 to 35 , the Lithuanian past iterative form appears, compare also the low -mentioned dialectal example 38.

Dialectal examples:

[37] Gerai ar negerai, jaigu cik kokias ti pasakis kad tep — ir viskas.

[38] - Ti, kap acimenu, dar seniau, kap mama vis aidavo - ti močiutes tas kapas - vis prisodzina tu geliu, prisimenu tokios getukes vis augdavo.

[39] Ti kokias vakar pasakojo per radiju, kad po Nauju metu kap kas pabrangs.

\subsubsection{The meaning of proper universality}

Compound phrases containing the particle bet are a Lithuanian unambiguous exponent of the meanings of proper universality. The particle bile is a dialectal equivalent, probably borrowed from Polish. However, unlike the Polish byle, usually meaning - not attach importance to choose something, the dialectal bile is a pure exponent of proper universality, devoid of any subjective assessment by the speaker. In Polish, the equivalent of the Lithuanian and dialectal phrases are compound phrases containing the particle -kolwiek. However, it should be emphasized that the Polish forms containing the particle -kolwiek are not an unambiguous exponent of the meanings of proper universality. They can express as well the meanings of habitual universality, compare the above-mentioned example 36. Hence, it is possible to interpret the Polish phrases containing the particle -kolwiek as 'almost always' / 'always when' / 'almost everyone'/ 'whoever' / 'almost everywhere'/ 'wherever' etc. Therefore, in practice, the Lithuanian unambiguous exponents with the particle bet correspond with various structures that absolutely and unambiguously express universal quantification (for each $\mathrm{x}$ belonging to the set $\mathrm{X}$, it is true that $(\mathrm{Px}))$, compare in the below-mentioned examples the Polish wszelkie dziatanie (40), bez względu na okoliczności (41), z dowolnego materiału (42) etc. 
Table 5. Exponents of proper universality in Polish, Lithuanian and the Lithuanian local dialect of Puńsk - contrastive comparison.

\begin{tabular}{|l|l|l|}
\hline \multicolumn{1}{|c|}{ Polish } & \multicolumn{1}{|c|}{ Lithuanian } & \multicolumn{1}{|c|}{ Local dialect of Puńsk } \\
\hline $\begin{array}{l}\text { series of lexemes with } \\
\text { the particle -kolwiek, e.g. } \\
\text { jakikolwiek }\end{array}$ & $\begin{array}{l}\text { series of lexemes with the } \\
\text { particle bet, e.g. bet koks } \\
\text { particle bile, e.g. bile } \\
\text { kokias } \\
\text { [series of lexemes with the } \\
\text { particle bet] }\end{array}$ \\
\hline $\begin{array}{l}\text { series of lexemes with the } \\
\text { particle if only, e.g. any } \\
\text { knick-knack }\end{array}$ & perfect negation & perfect negation \\
\hline &
\end{tabular}

[40] Kodèl domiuosi visokiais niekais, bet kokia ì rankas pakliuvusią smulkmena? Dlaczego zajmowałem się byle bzdurą, byle wpadającym w rękę nieważnym drobiazgiem?

[41] Tam tikrą laiką buvo populiari (uoliai laikraščiu skleidžiama) pažiūra, kad mąstantis okeanas, kuris supa visą Soliari, yra gigantiškos smegenys, kurios, besivystydamos milijonus metų, pranoko mūsų civilizaciją. Tai esąs kažkoks „kosminis jogas", išminčius, įkūnyta visažinybè, kuri jau seniai suvokè bet kokios veiklos bevaisiškumą ir todèl kategoriškai atsisako su mumis bendrauti.

Przez pewien czas popularny był (rozpowszechniany gorliwie przez prasę codzienną) pogląd, że myślący ocean, który opływa całą Solaris, jest gigantycznym mózgiem, przewyższającym naszą cywilizację o miliony lat rozwoju, że to jakiś „kosmiczny yoga”, mędrzec, upostaciowana wszechwiedza, która dawno już pojęła płonność wszelkiego działania i dlatego zachowuje wobec nas kategoryczne milczenie.

[42] Pilotas, kuris nesugeba bet kokiom aplinkybèm susiorientuoti, ar koks reiškinys trunka penkias sekundes, ar dešimt, ne ko tevertas.

Pilot, który nie potrafi bez względu na okoliczności zorientować się, czy jakieś zjawisko trwa pięć sekund czy dziesięć, nigdy nie będzie wiele wart.

[43] O manekenas, lèlè, šuns ar medžio statulèlè, išskaptuota iš bet kokios medžiagos, būna tučtuojau nukopijuojami.

Natomiast manekin, ludzka kukła, posążek psa czy drzewa wyrzeźbiony $z$ dowolnego materiatu kopiowany jest natychmiast.

[44] Gal tai ir Amsterdamas, nesu buvęs Olandijos.

Może i jest to Amsterdam, nigdy nie byłem w Holandii. 
In example 40, the Lithuanian bet and the Polish byle correspondence is demonstrated. On the basis of the experimental Polish-Lithuanian corpus data, the equivalence is found to be relatively more often noted than the expected correspondence of the Lithuanian bet to the Polish -kolwiek. It appears that the Polish exponent byle, although marked subjectively as a rule, is an unambiguous exponent of proper universality. However, if the addresser tends to attach importance to selection, pros and cons, the choice of the Polish exponent byle is inadvisable. Then, the alternative Polish phrases with the particle -kolwiek not always turn out to be most accurate (quantification ambiguity) and tend to be replaced with a description guaranteeing the absoluteness of choice, in other words - the possibility of choice of every element belonging to the potential set.

Dialectal example:

[45] Gerai, kad ir bile ku suvałgo, bile ne ałkanas būna.

\section{Summary}

The contrastive set of exponents of the semantic category of definiteness / indefiniteness in Polish, Lithuanian and the Lithuanian local dialect Puńsk in Poland demonstrates a number of substantial formal differences. First, the Lithuanian codes strictly distinguish the particular quantification meanings. The manifestation of this distinction are highly specialized exponents which are being used for expressing only and exclusively one quantification meaning. The Polish language does not implement such a rigorous assigning of the forms to the particular meanings, with the exception of the Polish byle. It means that the same Polish exponents are used to convey different quantification contents. In consequence, the quantification understatement phenomenon is much more frequent in Polish than in Lithuanian or in the local dialect of Puńsk. The quantification understatement in Polish is not only a feature of the nominal phrase. In the verbal phrase, the quantification understatement is more distinct. As far as in Lithuanian or the local dialect of Puńsk some quantification meanings result from just using the verbal form, in Polish, as a matter of fact, a particular quantification meaning is seen in context (e.g. the cooperation of particular verbal forms with pronouns, e.g. wtedy przyszedt 'then he came', with adverbs, e.g. zazwyczaj przychodzit 'he used to come' etc.), in context or from the general minimum non-linguistic knowledge that the addressee and the addresser share, e.g. Wista wpada do morza 'the Vistula flows into the sea' (general meanings); Cisza. Sylwia czyta 'Quiet, Sylvia is reading' (uniqueness of the state); Sylwia juz czyta 'Sylvia is already able to read.' (general meanings).

The Lithuanian local dialect of Puńsk in Poland is marked by a certain influence of Polish. One of the aspects of this influence is loss of using the compound declension of adjectives, participles and participle-like forms in the function of habitual universality (complete process) as well as in the function of uniqueness of the element or the set (drawing-to-a-close process). A further aspect of the influence is portmanteau (matching) of the Lithuanian literary form of the kaž- type (e.g. kažkokias) with the consuetude (custom) characteristic for its most frequent Polish equivalent - that is, pronouns and adverbs of the -ś type (e.g. ktoś, gdzieś). 
Therefore, the highly specialized forms of the $k a \check{z}$ - type borrowed from Lithuanian (unambiguous exponents of proper existentiality) by users of the local dialect of Puńsk can be also used in the meaning of habitual universality. The possible dialectal borrowing of bile, compare the Polish byle should also be taken into consideration. However, it should be mentioned that a dialectal phrase is usually devoid of the subjective assessment by the addresser.

The article does not analyze the relation between the particular flexemes of the verb (prefixed/non-prefixed forms, perfective/imperfective stems, with the distinction of three different stems for each lexeme) and the predisposition to express the particular quantification meanings. In consequence, the quantification meanings of the Lithuanian past, past frequentative, perfect, past continuative, and future being in connection with the above-mentioned features have been omitted.

A separate analysis, in terms of expressing the meanings of definiteness/indefiniteness, should be put into effect for the use of Lithuanian participles in the verbum finitum position, e.g. in modal sentences. Moreover, they tend to be used in absolute structures and other syntactic structures, whose content is demonstrated in Polish with the help of compound sentences, e.g. Lith. Atvažiave i Varšuva lietuviai nakvoja viešbutyje. - Pol. Litwini, którzy przyjechali do Warszawy, nocuja whotelu.

\section{References}

Dimitrova, L., Koseska-Toszewa, V., Roszko, D., Roszko, R. 2010. Application of Multilingual Corpus in Contrastive Studies (on the example of the Bulgarian-PolishLithuanian Parallel Corpus), Cognitive Studies / Etudes Cognitives 10 (217-239).

Koseska, V., Gargov, G. 1990. Бблгарско-полска съпоставителна граматика. Том 2. Семантичната категория определеност/неопределеност. София.

Macukonienè, J, Markevičienè, Ž. 2006. Būdvardžio ypatumai Lenkijos lietuviu šnektoje, Acta Baltico-Slavica. Archeologia Historia Ethnographia et Linguarum Scienta, vol. 30: 533-540.

Roszko, D. 2006. Funkcjonalne odpowiedniki litewskiego perfectum w litewskiej gwarze puńskiej $i$ w języku polskim, Warszawa.

Roszko, D. \& Roszko, R. 2009. Morphosyntactic Specifications for Polish and Lithuanian. [Description of Morphosyntactic Markers for Polish and Lithuanian Nouns within MULTEXT-East Morphosyntactic Specifications (Version 3.0 May 10th, 2004)] - Representing Semantics in Digital Lexicography Innovative Solutions for Lexical Entry Content in Slavic Lexicography, MONDILEX Fourth Open Workshop Warsaw, Poland, 29 June - 1 July, 2009, SOW Publishing House, Warsaw.

Roszko, D. \& Roszko, R. to appear. Polsko-litewska gramatyka konfrontatywna.

Roszko, R. 1993. Wyktadniki modalności imperceptywnej w języku polskim i litewskim, SOW, Warszawa.

Roszko, R. 2004. Semantyczna kategoria określoności/nieokreśloności w języku litewskim (w zestawieniu z językiem polskim), SOW, Warszawa. 